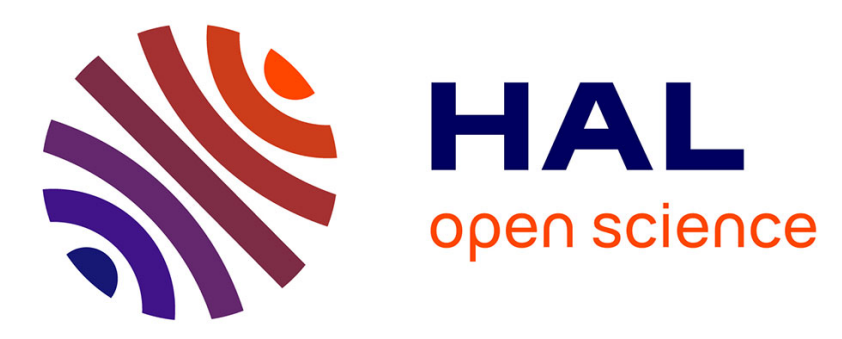

\title{
Modulation by colonic fermentation of LES function in humans
}

Thierry Piche, Franck Zerbib, Stanislas Bruley Des Varannes, Christine

Cherbut, Younès Anini, Claude Roze, Alain Le Quellec, Jean-Paul Galmiche

\section{- To cite this version:}

Thierry Piche, Franck Zerbib, Stanislas Bruley Des Varannes, Christine Cherbut, Younès Anini, et al.. Modulation by colonic fermentation of LES function in humans. AJP - Gastrointestinal and Liver Physiology, 2000, 278 (4), pp.G579-G584. hal-02686198

\section{HAL Id: hal-02686198 https: / hal.inrae.fr/hal-02686198}

Submitted on 1 Jun 2020

HAL is a multi-disciplinary open access archive for the deposit and dissemination of scientific research documents, whether they are published or not. The documents may come from teaching and research institutions in France or abroad, or from public or private research centers.
L'archive ouverte pluridisciplinaire HAL, est destinée au dépôt et à la diffusion de documents scientifiques de niveau recherche, publiés ou non, émanant des établissements d'enseignement et de recherche français ou étrangers, des laboratoires publics ou privés. 
Thierry Piche, Frank Zerbib, Stanislas Bruley Des Varannes, Christine Cherbut, Younès Anini, Claude Roze, Alain le Quellec and Jean-Paul Galmiche

Am J Physiol Gastrointest Liver Physiol 278:578-584, 2000.

You might find this additional information useful...

This article cites 32 articles, 9 of which you can access free at:

http://ajpgi.physiology.org/cgi/content/full/278/4/G578\#BIBL

This article has been cited by 1 other HighWire hosted article:

No effect of added \{beta\}-glucan or of fructooligosaccharide on appetite or energy intake

H. P. Peters, H. M Boers, E. Haddeman, S. M Melnikov and F. Qvyjt

Am. J. Clinical Nutrition, January 1, 2009; 89 (1): 58-63.

[Abstract] [Full Text] [PDF]

Medline items on this article's topics can be found at http://highwire.stanford.edu/lists/artbytopic.dtl on the following topics:

Biochemistry .. Fermentation

Biochemistry .. Lactose

Biochemistry .. Short Chain Fatty Acids

Physiology .. Esophagogastric Junction

Medicine .. Fasting

Physiology .. Humans

Updated information and services including high-resolution figures, can be found at:

http://ajpgi.physiology.org/cgi/content/full/278/4/G578

Additional material and information about AJP - Gastrointestinal and Liver Physiology can be found at: http://www.the-aps.org/publications/ajpgi

This information is current as of September 6, 2010 .

AJP - Gastrointestinal and Liver Physiology publishes original articles pertaining to all aspects of research involving normal or abnormal function of the gastrointestinal tract, hepatobiliary system, and pancreas. It is published 12 times a year (monthly) by the American Physiological Society, 9650 Rockville Pike, Bethesda MD 20814-3991. Copyright @ 2000 by the American Physiological Society. ISSN: 0193-1857, ESSN: 1522-1547. Visit our website at http://www.the-aps.org/. 


\title{
Modulation by colonic fermentation of LES function in humans
}

\author{
THIERRY PICHE, ${ }^{1}$ FRANK ZERBIB, ${ }^{1}$ STANISLAS BRULEY DES VARANNES, ${ }^{1}$ \\ CHRISTINE CHERBUT, ${ }^{2}$ YOUNÉS ANINI, ${ }^{3}$ CLAUDE ROZE, ${ }^{3}$ ALAIN LE QUELLEC, 4 \\ AND J EAN-PAUL GALMICHE ${ }^{1}$. \\ IInstitut National de la Santé et de la Recherche Médicale (INSERM) Unité 539, Centre de \\ Recherches en Nutrition Humaine, Centre Hospitalier UniversitaireHôtel Dieu, 44035 Nantes \\ Cedex, France; ${ }^{2}$ Institut National de la Recherche Agronomique, Nantes, France; ${ }^{3}$ INSERM \\ Unité 410, Faculté X Bichat, Paris, France; and ${ }^{4}$ INSERM Unité 376, Montpellier, France.
}

\begin{abstract}
Piche, Thierry, Frank Zerbib, Stanislas Bruley des Varannes, Christine Cherbut, Younès Anini, Claude Roze, Alain Le Quellec, and J ean-Paul Galmiche. Modulation by col onic fermentation of LES function in humans. Am J Physi ol Gastrointest Liver Physi ol 278: G578-G584, 2000.Colonic fermentation of carbohydrate has been shown to influence gastric and intestinal motility. Our aim was to investigate the effects of colonic infusion of lactose and short-chain fatty acids (SCFAs) on lower esophageal sphincter (LES) function in humans. LES pressure (LESP), transient relaxations of LES (TLESRs), and esophageal pH were monitored over $6 \mathrm{~h}$ on 4 different days in 7 heal thy volunteers. After $1 \mathrm{~h}$ of baseline recording, the effects of different colonic infusions ( $270 \mathrm{ml}$ of isotonic or hypertonic sal ine, $30 \mathrm{~g}$ lactose, or $135 \mathrm{mmol}$ SCFAs) were tested in fasting conditions and after a standard meal. Peptide YY (PYY) and oxyntomodulin (OLI) were also measured in plasma. Both lactose and SCFA infusions increased the number of TLESRs as well as the proportion of TLESRs associated with acid reflux episodes, but saline solutions did not. The postprandial fall of LESP was enhanced by previous SCFA infusion. Plasma PYY and OLI increased similarly after all colonic infusions. Colonic fermentation of lactose markedly affected LES function, and this effect was reproduced by SCFA infusion. Whether the mechanisms of this feedback phenomenon are of hormonal nature, neural nature, or both remains to be determined.
\end{abstract}

esophageal manometry; short-chain fatty acids; gastroesophageal reflux; peptideYY; oxyntomodulin

ALTHOUGH TRANSIENT LOWER ESOPHAGEAL sphincter relaxations (TLESRs) represent the main mechanism associated with the occurrence of reflux episodes (4, 5, 11, 19, 24), both in healthy subjects and in patients with gastroesophageal reflux (GER) disease, little is known about the factors involved in their occurrence. They can be triggered by gastric distension $(11,18)$ and through activation of mechanoreceptors located in the subcardial area (7) and are closely related to postprandial relaxation of the proximal stomach $(32,33)$.

The costs of publication of this article were defrayed in part by the payment of page charges. The article must therefore be hereby marked "advertisement" in accordance with 18 U.S.C. Section 1734 solely to indicate this fact.
Exposure of the distal gut to nutrients contributes to regulation of gastrointestinal motility in humans. This phenomenon was first referred to as the ileal brake, since the infusion of fatty acids $(6,10,25,26,29)$ or complex carbohydrates $(13,16)$ into the ileum delayed gastric emptying $(13,16)$ and sl owed transit time $(6,10$, 26). Colonic fermentation is a likely regulator of gastrointestinal motility, since $2-20 \%$ of ingested starch escapes digestion in the small intestine under physiol ogical conditions (27). Most carbohydrates are metabolized by colonic bacterial flora into short-chain fatty acids (SCFAs) and hydrogen. In healthy vol unteers, we recently showed that colonic fermentation of ingested lactulose as well as direct colonic infusion of a mixture of SCFAs in the cecum resulted in a marked dosedependent relaxation of the proximal stomach, as measured with an electronic barostat (22). The mechanisms involved in the ileocolonic brake remain largely obscure, nor is it known how the presence of SCFAs in the col on activates the feedback mechanism. Attention has focused on the possible role of digestive peptides such as peptide YY (PYY) and proglucagon-derived peptides [i.e., oxyntomodulin (OLI)] because they are colocalized and released from endocrine $L$ cells of the distal small intestine. However, conflicting results have been reported so far $(13,21,22)$.

Whether lower esophageal sphincter (LES) motility could also be affected by exposure of the colon to malabsorbed carbohydrates is presently unknown. We therefore hypothesized that a feedback mechanism could exist between col onic metabolic activity and LES motility.

The aims of the present study were 1) to investigate the motor activity of LES in response to colonic infusions of lactose, a frequently mal absorbed disaccharide, and of SCFAs, the main endproducts of lactose colonic fermentation, and 2) to determine whether circulating levels of PYY and OLI may be involved in the changes in LES motility.

\section{METHODS}

\section{Subjects}

E ight healthy volunteers (five men and three women; mean age $24.5 \mathrm{yr}$; age range 22-31) were studied on two separate 
occasions. The subjects were free of any gastrointestinal complaint and were not taking any medication known to alter esophageal motor function or gastric emptying. They gave their informed written consent, and the protocol was approved by thelocal research ethics committee (ComitéConsultatif pour la Protection des Personnes dans la Recherche Biomédicale Numéro 2, Région des Pays de Loire).

\section{Study Design}

The study was designed as two sets of experiments, with a washout interval ranging from 4 to 8 wk (Fig. 1). The day before the first tests, after fasting overnight, subjects were intubated with a double-lumen polyvinyl tube fitted with a radiopaque catheter with an inflatable latex balloon at its tip and a perfusion site $10 \mathrm{~cm}$ from the end of the tube. The latex balloon was inflated with $25 \mathrm{ml}$ of air when the radiopaque catheter had migrated beyond the ligament of Treitz and was deflated when the injection port of the tube had reached the cecum (confirmed by fluoroscopy). The assembly was then fixed to the nostril for esophageal motility and $\mathrm{pH}$ recordings.

Each set of experiments was performed on two consecutive days. Subjects were studied in a semirecumbent position, and an antecubital venous catheter was used for blood sampling. Two types of solutions were administered in random order and in single-blind fashion.

In the first set of experiments, $270 \mathrm{ml}$ of saline and lactose solutions, prewarmed at $37^{\circ} \mathrm{C}$ and adjusted for $\mathrm{pH}$ (5.6-6.1), were infused in randomized order into the proximal colon during a $90-\mathrm{min}$ period ( $3 \mathrm{ml} / \mathrm{min}$ ) by means of a peristaltic pump. The saline solution $(9 \mathrm{~g} / \mathrm{l})$ corresponded to $150 \mathrm{mmol} / \mathrm{l}$. The osmolality of an isotonic saline solution is $300 \mathrm{osmol} / \mathrm{kg}$. The lactose solution consisted of $111 \mathrm{~g}$ of $\mathrm{D}$-lactose diluted in 1 I of isotonic saline. Because the osmolalities of saline and lactose are additive, the osmolality of this solution was 600 osmol $/ \mathrm{kg}$. Therefore, the amount perfused $(270 \mathrm{ml})$ corresponded to $30 \mathrm{~g}$ of $\mathrm{D}$-lactose.

In the second set of experiments, hypertonic saline and a mixture of SCFAs were tested. The hypertonic saline solution consisted of $\mathrm{NaCl} 36 \mathrm{~g} / \mathrm{l}$, corresponding to $600 \mathrm{mmol} / \mathrm{l}$. The osmolality of this solution was $1,200 \mathrm{osmol} / \mathrm{kg}$, and the amount infused was $162 \mathrm{mmol}$. The SCFA solution consisted of a mixture of $500 \mathrm{mmol}$ SCFAs diluted in 1 I of isotonic saline. The composition of the SCFA was $70 \%$ acetic acid, $20 \%$ propionic acid, and $10 \%$ butyric acid. The osmolality of this solution was 1,200 osmol/kg, and the amount infused was 135 $\mathrm{mmol}$. The pH of solutions was kept constant (i.e., 5.6-6.1), as in the first set of experiments.
After $1 \mathrm{~h}$ of baseline $\mathrm{pH} /$ pressure recording, the tested solution was infused into the proximal colon for a 90-min period. The subjects sat up to eat a standard 324-kcal meal at 11 AM (i.e., $30 \mathrm{~min}$ before the end of colonic infusions) that consisted of an egg, $10 \mathrm{~g}$ of butter, 2 rusks, 1 slice of ham, 100 $\mathrm{ml}$ of orange juice and $100 \mathrm{ml}$ of water. The volunteers were asked to eat the meal over a 20-min period. Esophageal motility and $\mathrm{pH}$ werethen further monitored for four consecutive hours. At the end of the recording, the subjects were allowed to walk, and a starch-free meal was served at 8 PM. On day 2 , the procedures were similar to those of day 1 , except that the solution infused into the proximal colon was changed for the other one in a random fashion.

For analysis, the overall 6-h recording time was divided into three periods: the first hour corresponded to baseline fasting, the second to colonic infusions in the fasting state (i.e., infusion fasting), and the third to the $4 \mathrm{~h}$ after the meal (i.e., postprandial).

\section{Assessments}

LES motility. A standard motility catheter fitted with a 6-cm Dent sleeve (Arndorfer Medical Specialties, Milwaukee, WI ) was used to monitor esophageal pressures. The assembly was swallowed and positioned so that pressures could be recorded from the LES (sleeve), fundus $(2 \mathrm{~cm}$ below the sleeve), esophageal body (side holes 5 and $10 \mathrm{~cm}$ proximal to the sleeve), and pharynx (side hole $28 \mathrm{~cm}$ proximal to the sleeve to detect swall owing). The catheter was perfused at 0.5 $\mathrm{ml} / \mathrm{min}$ with a low-compliance hydraulic capillary infusion system (Arndorfer Medical Specialties) driven by a pressure head of nitrogen. The infusion system was connected to pressure transducers (Gould P23D; Gould I nstruments, Ballainvillers, France), and the output was displayed on a multichannel pen recorder running at a speed of $2.5 \mathrm{~mm} / \mathrm{s}$ (Gould ES 1000; Gould I nstruments).

Resting LES pressure (LESP) was measured every 3 min and averaged over 15-min intervals. Mean resting LESP was defined as the average of the baseline period (i.e., baseline fasting), and was used to determinethe variation of LES tone $(\Delta \mathrm{P})$ during fasting infusions and the postprandial period. The maximal decrease of LESP $\left(\Delta \mathrm{P}_{\max }\right)$ was the mean of individual values of maximal variation of the LESP. Results are expressed in $\mathrm{mmHg}$.

TLESRs were defined according to Holloway et al. (12) as 1) a LES relaxation occurring in the absence of a pharyngeal swallow signal for $4 \mathrm{~s}$ before and $2 \mathrm{~s}$ after the onset of the LES relaxation, 2) a LESP decrease of $\geq 1 \mathrm{mmHg} / \mathrm{s}, 3$ ) a time from

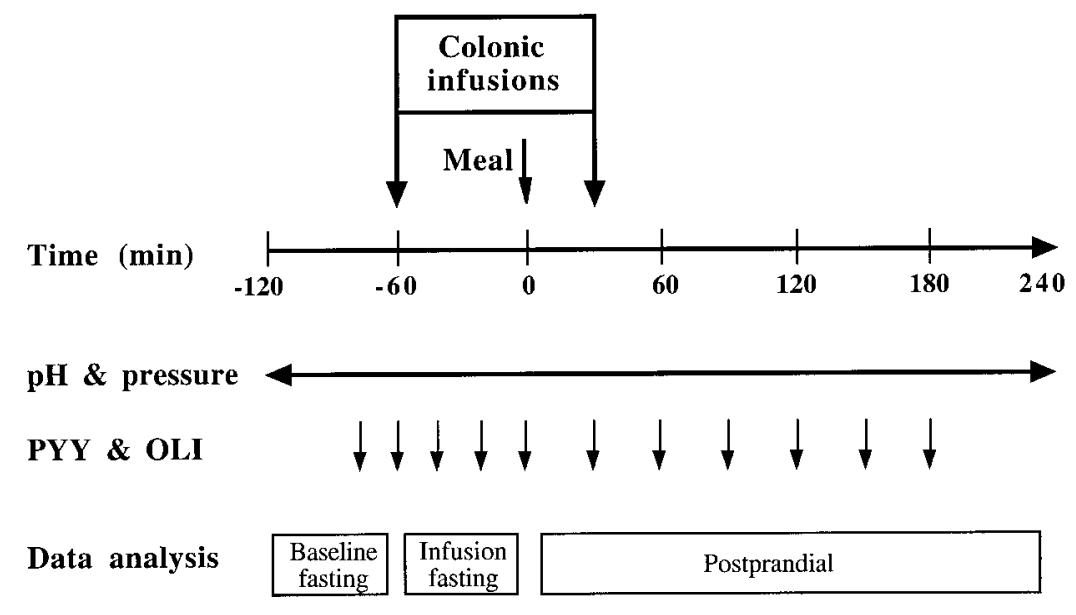

Fig. 1. Study design. PYY, peptideYY; OLI, oxyntomodulin. 


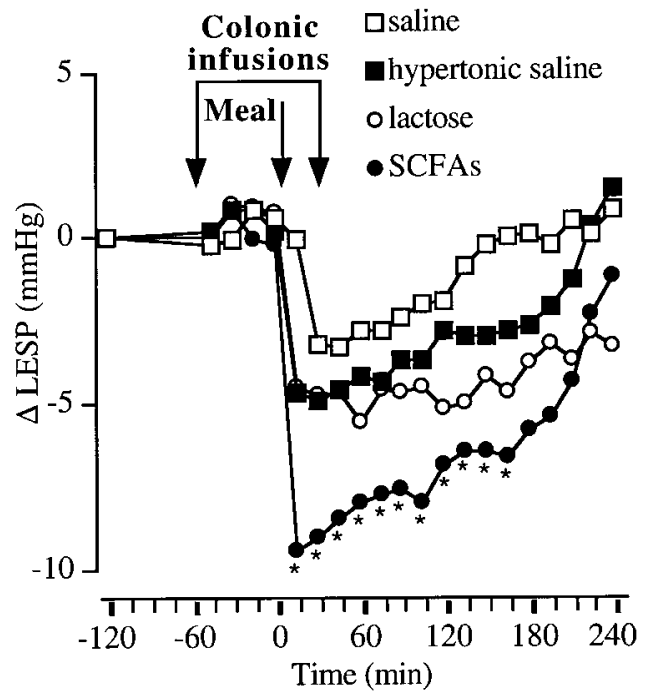

Fig. 2. Effects of colonic infusions ( $3 \mathrm{ml} / \mathrm{min}$ during $90 \mathrm{~min}$ ) on variation of lower esophageal sphincter pressure from baseline ( $\triangle$ LESP; mean values). After meal ingestion, $\Delta$ LESP was significantly greater with short chain fatty acids (SCFAs; area under curve, $* P<0.01)$ than with both saline solutions.

onset to complete relaxation of $\leq 10 \mathrm{~s}, 4)$ a nadir pressure of $\leq 2 \mathrm{mmHg}$, and 5) a LESP decrease to $\leq 2 \mathrm{mmHg}$ for $>10 \mathrm{~s}$ (excluding multiplerapid swallows).

$\mathrm{pH}$ monitoring. Esophageal $\mathrm{pH}$ was monitored using an antimony unipolar electrode (Medtronic Synectics, Stockhol $\mathrm{m}$, Sweden) positioned $5 \mathrm{~cm}$ above the proximal margin of the sleeve. The electrode was calibrated with $\mathrm{pH} 1$ and $\mathrm{pH} 7$ buffers before and at the end of each session. Signals from the $\mathrm{pH}$ electrode were synchronized with pressure signals, digitized and recorded by a portable datal ogger (Mark 3 Microdigitrapper, Medtronic Synectics), and then transferred to a computer for subsequent display and analysis.

$\mathrm{pH}$ records were analyzed manually. Acid reflux episodes were defined as an abrupt decrease of at least $2 \mathrm{pH}$ units for at least $5 \mathrm{~s}$ or, if $\mathrm{pH}$ was already below 4, a further abrupt decrease of at least $1 \mathrm{pH}$ unit for at least $5 \mathrm{~s}$ (31). E sophageal acid exposure was defined as the time below pH 4. Slow downward drifts of $\mathrm{pH}$ during several minutes were not scored as reflux episodes or counted in the evaluation of esophageal acid exposure.

In the analysis, reflux was considered to have accompanied a TLESR if an abrupt decrease of at least $2 \mathrm{pH}$ units occurred during LES relaxation. The LESP and the number of TLESRS were analyzed by two investigators (T. Piche and F. Zerbib), one of whom was blind to the solutions infused into the col on and unaware of the $\mathrm{pH}$ recording ( $\mathrm{F}$. Zerbib). In case of discrepancies, a third investigator (S. Bruley des Varannes) gave the conclusive analysis.
Hormonal assays. Blood samples were collected in glass tubes containing EDTA plus aprotinin, centrifuged at $1,200 \mathrm{~g}$ for $6 \mathrm{~min}$ at $4^{\circ} \mathrm{C}$ within $10 \mathrm{~min}$ of venipuncture, and then stored at $-30^{\circ} \mathrm{C}$ until assay. I mmunoreactive plasma PYY levels were measured by a sensitive and specific radioimmunoassay $(8,28)$. The antiserum (kindly provided by Dr. J . C. Cuber, INSERM U45, Lyon, France) was raised in New Zealand White rabbits immunized with unconjugated synthetic human PYY. The assays were performed in duplicate. The detection limit in plasma was $\sim 3 \mathrm{fmol} / \mathrm{ml}$. The antiserum cross-reacted $100 \%$ with human synthetic PYY-(1-36) and PYY-(3-36), whereas no significant cross-reaction occurred with bovine pancreatic polypeptide, human pancreatic polypeptide, and avian pancreatic polypeptide and only a slight cross-reaction with porcine neuropeptide Y. OLI determination was performed using an OL I COOH-terminal octapeptidespecific antibody, as described in detail elsewhere (15). The detection limit of the assay was $1 \mathrm{fmol} / \mathrm{ml}$.

\section{Statistical Analysis}

Results are expressed as means \pm SE. Postprandial variations of LESP and plasma levels of PYY and OLI were compared by ANOVA for repeated measurements. The number of TLESRs and reflux episodes were compared by one-way ANOVA and Fisher's test. Percentages of TLESRs associated with reflux episodes were compared with a contingency table. Correlation studies were performed using linear regression. Statistical analysis was conducted using Statview version 4.01 (Brain Power, Calabasas, CA). A P value $<0.05$ was considered significant.

\section{RESULTS}

The eight subjects completed the first set of experiments, but one refused to participate in the second set. Most subjects experienced mild side effects during lactose or SCFA infusions (bloating in five and four cases and diarrhea in two and three cases, respectively). Three subjects also complained of bloating while on hypertonic saline during the second set of experiments.

\section{LES Motility}

LES pressure Compared with baseline fasting, coIonic infusions (i.e., infusion fasting) did not significantly change resting LESP. As expected, LESP fell after the meal, and this fall was significantly more pronounced after colonic infusion of SCFAs (area under the curve, $\mathrm{P}<0.01$ ) compared with saline and hypertonic saline solutions (Fig. 2). The maximal decrease in LESP $\left(\Delta \mathrm{P}_{\max }\right)$ was observed after colonic infusion of SCFAs, and $\Delta \mathrm{P}_{\max }$ occurred later after colonic infusion

Table 1. Effect of col onic infusion of short-chain fatty acids, lactose, saline, and hypertonic sal ine solutions on postprandial changes of lower esophageal sphincter pressure from basel ine fasting

\begin{tabular}{ccccc}
\hline \hline & \multicolumn{2}{c}{ First Experiment, $\mathrm{n}=8$} & \multicolumn{2}{c}{ Second Experiment, $\mathrm{n}=7$} \\
\cline { 2 - 3 } Postprandial & Saline & Lactose & & Hypertonic Saline \\
\hline AUC, $\mathrm{mmHg} \cdot \min$ & $309 \pm 138$ & $933 \pm 331$ & $348 \pm 124$ & $1,591 \pm 416 *$ \\
$\Delta \mathrm{P}_{\max }, \mathrm{mmHg}$ & $-5.4 \pm 1.2$ & $-7.4 \pm 2.1$ & $-7.6 \pm 0.6$ & $-11.0 \pm 1.7$ \\
Time of $\Delta \mathrm{P}_{\max }, \min$ & $52.5 \pm 12.7$ & $101.2 \pm 30.5 \dagger \S$ & $42.9 \pm 8.9$ & $30.0 \pm 8.0$ \\
\hline
\end{tabular}

Data are means $\pm \mathrm{SE} . \Delta \mathrm{P}_{\max }$, mean of maximal variation of lower esophageal sphincter pressure (LESP) for all individual subjects, irrespective of time this peak occurred. Interval before $\Delta \mathrm{P}_{\max }$ (time of $\Delta \mathrm{P}_{\max }$ ) is expressed in minutes. $* \mathrm{P}<0.01$ vs. saline and hypertonic saline; $\uparrow P=0.03$ and $\S P=0.01$ vs. hypertonic saline and short-chain fatty acids (SCFAs), respectively. 


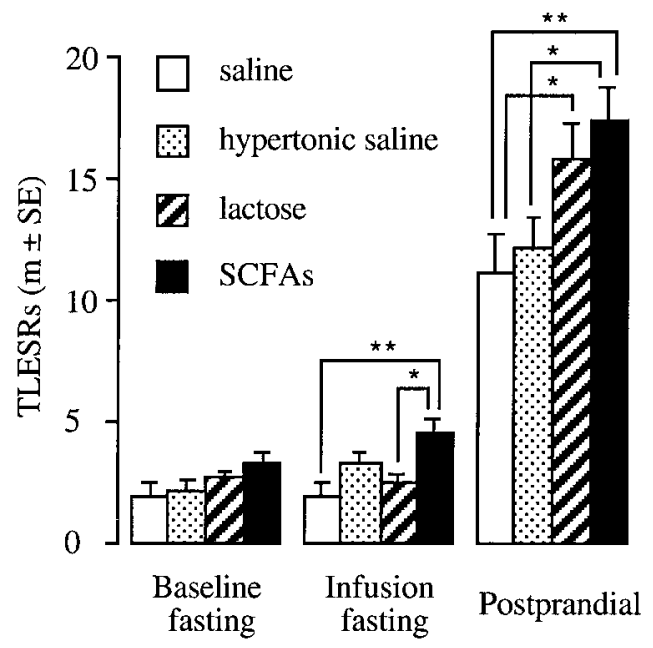

Fig. 3. Number of transient lower esophageal sphincter relaxations (TLESRs) during baseline fasting and after colonic infusions (fasting and postprandially). Values are means $\pm \mathrm{SE} ; * \mathrm{P}<0.05 ; * * \mathrm{P}<0.01$.

of lactose than after infusion of SCFAs $(P=0.01)$ or of both saline solutions $(P<0.05)$ (Table 1$)$.

TLESRs. The rates of TLESRs during the different periods are shown in Fig. 3. The rate of TLESRs was not significantly different between baseline fasting and infusion fasting in each group. During infusion fasting, SCFAs significantly increased the rate of TLESRS compared with saline $(4.4 \pm 0.6$ vs. $1.8 \pm 0.5$, respectively; $P=0.005)$, whereas lactose had no effect. The meal was followed by a significant increase in the rate of TLESRs, which was significantly greater after coIonic infusion of SCFAs (17.4 \pm 1.3$)$ and lactose (15.8 \pm 1.5) than after saline (11.1 $\pm 1.6 ; P<0.01$ and $P<0.05$, respectively) and hypertonic saline (12.2 $\pm 1.3 ; \mathrm{P}<$ 0.01 and not significant, respectively). At all times of the postprandial period, the rate of TLESRs was numerically higher after lactose and SCFA infusions than after saline, although the difference was only statistically significant during the third hour (Fig. 4). After meal ingestion, the peak number of TLESRs was

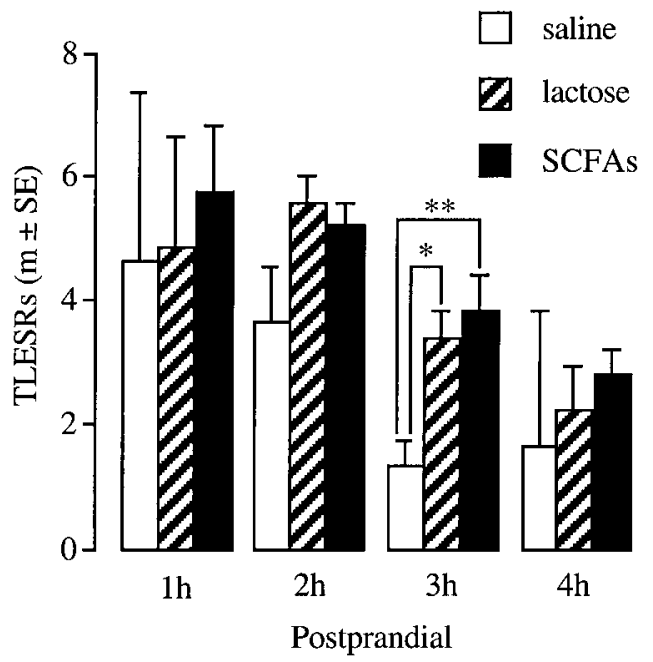

Fig. 4. Effect of colonic infusions of lactose and SCFAs on TLESRs in postprandial period. Values are means $\pm \mathrm{SE}$; $* \mathrm{P}<0.05$; **P $<0.01$.
Table 2. Effect of colonic infusion of SCFAs, lactose, saline, and hypertonic saline solutions on number of reflux episodes and esophageal acid exposure

\begin{tabular}{|c|c|c|c|c|c|}
\hline & \multirow{3}{*}{$\begin{array}{c}\text { Time, } \\
\text { min }\end{array}$} & \multirow{2}{*}{\multicolumn{2}{|c|}{$\begin{array}{l}\text { First Experiment, } \\
\qquad \mathrm{n}=8\end{array}$}} & \multicolumn{2}{|c|}{$\begin{array}{l}\text { Second Experiment, } \\
\qquad \mathrm{n}=7\end{array}$} \\
\hline & & & & Hyperton & \\
\hline & & Saline & Lactose & Caling & SCFAS \\
\hline \multicolumn{6}{|l|}{$\begin{array}{c}\text { Number of reflux } \\
\text { episodes }\end{array}$} \\
\hline Baseline fasting & 60 & $0.2 \pm 0.2$ & $0.4 \pm 0.3$ & $0.4 \pm 0.3$ & $0.7 \pm 0.4$ \\
\hline Infusion fasting & 60 & $0.8 \pm 0.4$ & $0.4 \pm 0.3$ & $0.7 \pm 0.3$ & $1.4 \pm 0.6$ \\
\hline Postprandial & 240 & $5.9 \pm 1.6$ & $8.0 \pm 2.4$ & $6.4 \pm 1.2$ & $10.9 \pm 2.5$ \\
\hline \multicolumn{6}{|c|}{$\begin{array}{l}\text { Esophageal acid } \\
\text { exposure, min }\end{array}$} \\
\hline Baseline fasting & 60 & $0.0 \pm 0.0$ & $0.0 \pm 0.0$ & $0.0 \pm 0.0$ & $0.0 \pm 0.0$ \\
\hline Infusion fasting & 60 & $0.1 \pm 0.0$ & $0.0 \pm 0.0$ & $0.1 \pm 0.0$ & $6.4 \pm 0.1$ \\
\hline Postprandial & 240 & $3.7 \pm 0.9$ & $7.2 \pm 3.3$ & $5.8 \pm 0.9$ & $7.7 \pm 2.0$ \\
\hline
\end{tabular}

Data are means \pm SE. None of the differences between solutions was statistically significant.

observed later after colonic infusion of lactose than after SCFAs (Fig. 4).

GER episodes. Most GER episodes occurred during the postprandial period. The number of postprandial reflux episodes was numerically but not significantly increased by colonic infusion of both SCFAs and lactose (Table 2). The average postprandial esophageal acid exposure tended to be longer after colonic infusions of SCFAs ( $7.7 \pm 2.1 \mathrm{~min})$ and lactose $(7.2 \pm 3.3 \mathrm{~min})$ than hypertonic saline $(5.8 \pm 1.0 \mathrm{~min})$ or saline $(3.8 \pm 0.9$ min), although the differences were not statistically significant.

Compared with baseline fasting, the number of TLESRs associated with a GER episode during the infusion fasting period was not significantly affected. In contrast, after the meal, colonic infusions of both lactose and SCFAs significantly $(P<0.05)$ increased the number of TLESR s associated with a GER episode, compared with saline (Fig. 5).

\section{PYY and OLI Plasma Levels}

Average plasma levels of PYY and OLI increased immediately after colonic infusions, and PYY rose more abruptly than OLI (Fig. 6). However, no significant difference was found between the different solutions infused. Conversely, meal ingestion did not produce a further increase in PYY and OLI plasma levels. No correlation was found between plasma PYY or OLI response and the number of TLESRs or LESP.

\section{DISCUSSION}

This study demonstrates that infusions of lactose or SCFAs into the col on markedly affected LES function in humans. The postprandial fall in LESP was more pronounced after colonic infusion of SCFAs, whereas the number of TLESRs increased after both lactose and SCFA colonic infusions. The proportion of TLESRs associated with reflux also increased.

Some methodological issues need to be considered first. For practical reasons, the experiments were per- 
formed on two separate occasions (i.e., saline vs. Iactose in the first set of experiments and then hypertonic saline vs. SCFAs in the second set). Therefore, the four solutions were not administered in a completely random order. In fact, we were concerned about losing some subjects because of the relative invasiveness of the procedures. However, despite mild side effects, all subjects except one tolerated the procedure quite well, thus allowing crossover comparison for 7 of them. Moreover, the order of the two sets of experiments was not randomized since the rationale of the second one (SCFAs) was to explain the results obtained in response to lactose fermentation. In other words, the second set of experiments would not have been performed if the results of the first one had been completely negative.

The dose of lactose administered (30 g), although comparatively large, was calculated by reference to a previous work (22) in which infusion of 90 mmol SCFAs into the colon induced a profound relaxation of the proximal stomach. This amount roughly corresponds to the production of SCFAs resulting from complete fermentation of $20 \mathrm{~g}$ of disaccharides (30). In the present study, $30 \mathrm{~g}$ of lactose were considered to approximate the amount malabsorbed in lactase deficiency after consumption of $50 \mathrm{~g}$ of lactose orally (i.e., 1 I of cow's milk). Hence, complete fermentation of $30 \mathrm{~g}$ of lactose would produce $\sim 135 \mathrm{mmol}$ of SCFAs, which corresponds to the quantity infused in the present experiments. Because of the mixing of this solution with colonic contents, the intracolonic concentrations of SCFAs were probably in the physiological or slightly supraphysiological range. The high proportion of subjects who experienced bloating and diarrhea further confirms that lactose infusion was consistently and effectively fermented by colonic flora.

The role of SCFAs in the observed effects is supported not only by the fact that exogenous SCFAs reproduced the effects of lactose but also by the delayed effect of
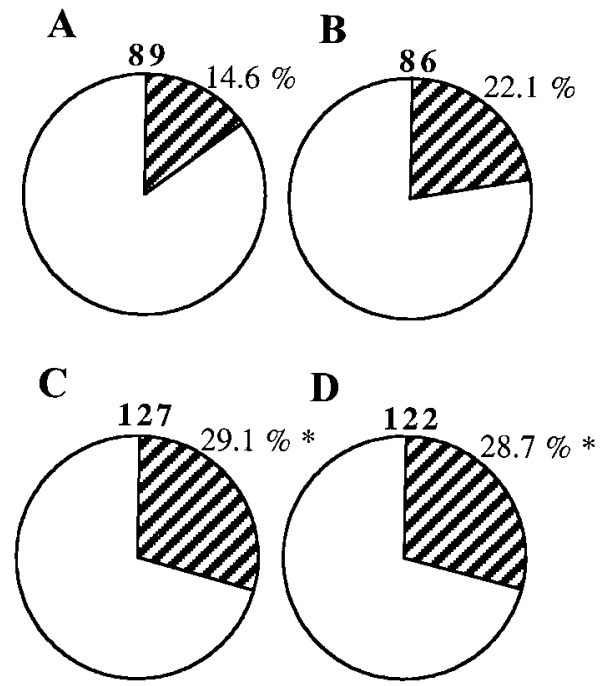

Fig. 5. Proportion of postprandial TLESRs associated with reflux (hatched areas) after colonic infusion of following solutions: $A$, saline; $B$, hypertonic saline; C, lactose; D, SCFAs. $* P=0.01$ vs. saline. Figures over circles indicate total number of TLESRs recorded over 4 h postprandially.
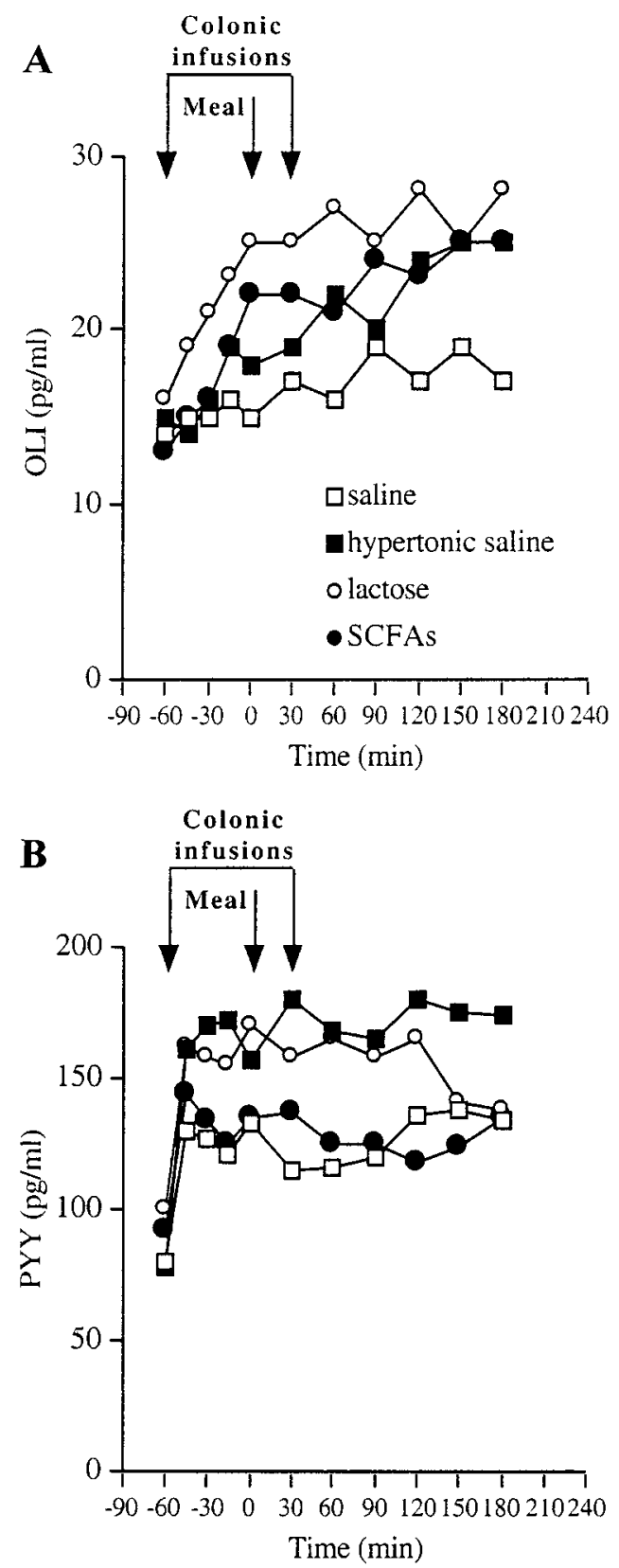

Fig. 6. Effects on OLI (A) and PYY (B) plasma levels (mean values in $\mathrm{pg} / \mathrm{ml}$ ) of colonic infusions ( $3 \mathrm{ml} / \mathrm{min}$ during $90 \mathrm{~min}$ ).

lactose compared with SCFA infusion. Indeed, the peak number of postprandial TLESRs, and the peak decrease of LESP, occurred later after colonic infusion of lactose than after SCFAs. Together, these findings suggest that colonic infusion of lactose modulated LES function through the production of SCFAs after colonic fermentation of the disaccharide.

Although SCFAs typically reproduced the effects of lactose infusion, other factors, such as $\mathrm{pH}$ or osmolality, were also influenced by the fermentation process. In our experiments, the $\mathrm{pH}$ of the solution was kept constant but did not necessarily reflect intraluminal $\mathrm{pH}$. Similarly, a subtle effect of osmolality cannot be entirely excluded, although it is noteworthy that the hypertonic saline solution (1,200 osmol/kg) was consis- 
tently less effective than the less-hypertonic lactose solution (i.e., $600 \mathrm{osmol} / \mathrm{kg}$ ). Therefore, it is likely that the effect (if any) of osmolality was of minor importance compared with that of SCFAs. Finally, it is al so possible that gas production after lactose infusion might have stimulated mechanoreceptors sensitive to distension (17).

The mechanisms triggered by lactose fermentation and SCFA infusion can affect LES motility either directly or indirectly via an action on proximal stomach and/or gastric emptying. Among the different neurohormonal pathways, the role of intestinal regulatory peptides should be considered first. Indeed, some studies have suggested that PYY and proglucagon-derived peptides such as OLI are released by fat (14) and/or carbohydrates (13) into the ileum (14) and colon (22). These peptides may therefore play a role in the socalled ileocolonic brake. However, despite a rapid increase in both PYY and OLI plasma levels after colonic infusion, this study confirms our previous results (22) suggesting that the release of these peptides is not related to specific nutrients but to mechanical stimulation of the colon. Other peptides that may play a major role in triggering TLESRs (e.g., CCK) were not specifically checked in this study because of the colonic site of infusion. F urthermore, the rapid onset of LES response to colonic infusion of SCFAs rather suggests a neural pathway. Interestingly, Azpiroz and Malagelada (1) showed in dogs that gastric relaxation induced by intestinal nutrients was mediated by fibers contained in the vagus nerves. Moreover, Gué et al. (9) observed that colonic distension-induced inhibition of gastric motility was suppressed by hexamethonium, suggesting that nicotinic ganglionic receptors are involved in the inhibitory cologastric pathway. They also showed that $\kappa$-agonists such as fedotozine are able to block col onic distention-induced inhibition of gastric motility and emptying. In summary, it is conceivable that col onic exposure to SCFAs may influence LES function through a neural mediation.

Finally, TLESRs are triggered by gastric distension through a vago-vagal reflex involving nonadrenergicnoncholinergic neurons (2). Although a direct effect of col onic fermentation on LES motility through unidentified specific pathways cannot be completely excluded, several studies have suggested that gastric motility may play an important role. Indeed, we have shown that oral lactulose administration as well as colonic exposure to exogenous SCFAs markedly influenced gastric tone (22). Colonic exposure to SCFAs may also increase the number of reflux episodes by delaying gastric emptying. For example, J ain et al. (13) have reported that blockade of carbohydrate digestion by an amylase inhibitor induced colonic fermentation associated with slower gastric emptying. In addition, the gastric emptying of a second meal was delayed after ingestion of a first meal containing unabsorbed carbohydrates (16). We and others have also observed either more prolonged (20) or profound (34) relaxation of the proximal stomach in response to a liquid meal in patients with GER disease (34). It is conceivable that a more profound relaxation of the proximal stomach can affect the mechanisms triggering TLESRs. Finally, SCFA production may result in decreased gastric tone and delayed emptying, conditions known to be associated with GER disease $(23,34)$.

The relevance of our findings to clinical situations is unclear. Although our healthy volunteers did not report heartburn or regurgitation, extrapolation from these negative findings to patients with clinical GER disease is not feasible. Similarly, the role of LES dysfunction or gastric motor disturbances on symptoms observed in patients with lactase deficiency cannot be ascertained.

In summary, we have shown that colonic fermentation, through the production of SCFAs, exerts a controlled feedback on LES motor function. Whether the mechanisms of this phenomenon are of hormonal nature, neural nature, or both remains to be determined.

This work was supported by a grant from the "Délègation à la Recherche Clinique de Nantes."

Address for reprint requests and other correspondence: J. P Galmiche, CRI INSERM 95-08. Centre de Recherches en Nutrition Humaine. CHU-Hôtel Dieu, 44035 Nantes Cedex, France (E-mail: galmiche@easynet.fr).

Received 27 May 1999; accepted in final form 3 November 1999.

\section{REFERENCES}

1. Azpiroz $\mathbf{F}$ and Malagelada J R. Vagally mediated gastric relaxation induced by intestinal nutrients in the dog. Am J Physiol Gastrointest Liver Physiol 251: G727-G735, 1986.

2. Boulant J , Fioramonti J , Dapoigny M, Bommelaer G, and Bueno L. Cholecystokinin and nitric oxide in transient lower esophageal sphincter relaxation to gastric distension in dogs. Gastroenterol ogy 107: 1059- 1066, 1994.

3. Christl SU, Murgatroyd PR, Gibson GR, and Cummings J H. Production, metabolism and excretion of hydrogen in the large intestine. Gastroenterol ogy 102: 1269-1277, 1992.

4. Dent J , Dodds WJ , Friedman RH, Sekiguchi T, Hogan WJ , Arndorfer RC, and Petrie DJ . Mechanism of gastroesophageal reflux in recumbent asymptomatic human subjects. J Clin Invest 65: 256-267, 1980.

5. Dodds W] , Dent J , Hogan J F, Helm R, Hauser GK, Patel GK, and Egide MS. Mechanisms of gastroesophageal reflux in patients with reflux esophagitis. N Engl J Med 307: 1547-1552, 1982.

6. Dreznik Z, Brocksmith D, Meiniger TA, and Soper NJ . Inhibitory effect of ileal oleate on postprandial motility of the upper gut. Am J Physiol Gastrointest Liver Physiol 261: G458G463, 1991.

7. Franzi SJ , Martin CJ, Cox MR, and Dent J . Response of canine lower esophageal sphincter to gastric distension. Am J Physiol Gastrointest Liver Physiol 259: G380-G385, 1990.

8. Fu-Cheng X, Anini Y, Chariot J , Voisin T, GalmicheJ P, and Rozé C. Peptide YY release after intraduodenal, intraileal and intracolonic administration of nutrients in rats. Pflügers Arch 431: 66- 75, 1995.

9. Gué $\mathbf{M}, \mathbf{J}$ unien $\mathbf{J} \mathbf{L}$, and Buéno $\mathbf{L}$. The $\kappa$ agonist fedotozine modulates colonic distension-induced inhibition of gastric motility and emptying in dogs. Gastroenterology 107: 1327-1334, 1994.

10. Holgate AM and Read NW. Effect of ileal infusion of intralipid on gastrointestinal transit, ileal flow rate, and carbohydrate absorption in humans after ingestion of a liquid meal. Gastroenterol ogy 88: 1005-1011, 1985.

11. Holloway RH, Hongo M, Berger $\mathbf{K}$, and McCallum RW. Gastric distension: a mechanism for post-prandial gastroesophageal reflux. Gastroenterology 89: 779- 784, 1985. 
12. Holloway RH, Penagini R, and Ireland A. Criteria for objective definition of transient lower esophageal sphincter relaxation. AmJ Physiol Gastrointest Liver Physiol 268: G128-G133, 1995.

13. J ain NK, Boivin M, Zinsmeister AR, Brown ML, and Malagelada J R. Effect of ileal perfusion of carbohydrates and amylase inhibitor on gastrointestinal hormones and emptying. Gastroenterology 96: 377- 387, 1989.

14. Layer P, Peschel S, Schlesinger T, and Goebell H. Human pancreatic secretion and intestinal motility: effects of ileal nutrient perfusion. Am J Physiol Gastrointest Liver Physiol 258: G196-G201, 1990.

15. Le Quellec A, Kervran A, Blache P, Ciurana AJ, and Bataille D. Oxyntomodulin-like immunoreactivity: diurnal profile of a new potential enterogastrone. J Clin Endocrinol Metab 74: 1405-1409, 1992.

16. Lin HC, Moller NA, Wolinski MM, Kim BH, Doly J E, and Meyer J H. Sustained slowing effect of lentils on gastric emptying of solids in human and dogs. Gastroenterology 102: 787-792, 1992.

17. Maggi CA, Manzini S, and Meli A. Contribution of neurogenic and myogenic factors in the response of rat proximal colon to distension. Am J Physiol Gastrointest Liver Physiol 252: G447G457, 1987.

18. Martin CJ , Patrikios J , and Dent J . Abolition of gas reflux and transient LES relaxation by vagal blockade in the dog. Gastroenterology 91: 890-896, 1986.

19. Mittal RK, Stewart WR, and Schirmer BD. Effect of a catheter in the pharynx on the frequency of transient lower esophageal sphincter relaxations. Gastroenterology 103: 12361240, 1992.

20. Penagini R, Hebbard G, Horowitz M, Dent J , Bermingham $\mathbf{H}$, J ones K, and Holloway RH. Motor function of the proximal stomach and visceral perception in gastro-oesophageal reflux disease. Gut 42: 251-257, 1998.

21. Pironi L, Stanghellini V, Miglioli M, Corinaldesi R, Giorgio R, and Ruggeri E. Fat-induced ileal brake in humans: a dose-dependent phenomenon correlated to the plasma levels of peptideYY. Gastroenterol ogy 105: 733-739, 1993.

22. Ropert A, Cherbut C, Rozé C, LeQuellec A, Holst JJ, Fu-Cheng X, Bruley des Varannes S, and Galmiche J P. Colonic fermentation and proximal gastric tone in humans. Gastroenterology 111: 289-296, 1996.
23. Scarpignato C. Gastric emptying in gastroesophageal reflux disease and other functional esophageal disorders. Front Gastrointest Res 22: 223-259, 1994.

24. Schoeman MN, Tippett MD, Akkermans LMA, Dent J , and Holloway RH. Mechanisms of gastroesophageal reflux in ambulant healthy subjects. Gastroenterol ogy 108: 83- 91, 1995.

25. Soper NJ , Chapman NJ , Kelly KA, Brown ML, Phillips SF, and Go VLW. The "ileal-brake" after ileal pouch-anal anastomosis. Gastroenterol ogy 98: 111-116, 1990.

26. Spiller RC, Trotman IF, Adrian TE, Bloom SR, Misiewicz J J , and Silk DBA. Further characterisation of the "ileal brake" reflex in man-effect of ileal infusion of partial digests of fat, protein, and starch on jejunal motility and release of neurotensin, enteroglucagon, and peptideYY. Gut 29: 1042-1051, 1988.

27. Stephen AM, Haddad AC, and Philips SF. Passage of carbohydrate into the col on. Direct measurements in humans. Gastroenterology 85: 589-595, 1983.

28. Voisin T, Rouyer-Fessard C, and Laburthe M. Peptide YY/neuropeptide $Y$ receptors in small intestine: characterization, signal transduction, and expression during cell differentiation. Ann NY Acad Sci 611: 343-346, 1990.

29. Welch I, Cunningham KM, and Read NW. Regulation of gastric emptying by ileal nutrients in humans. Gastroenterology 94: 401-404, 1988

30. Wolin MJ and Miller TL. Carbohydrate fermentation. In: Human Intestinal Microflora, edited by Hentges DJ . New York: Academic, 1983, p. 147- 165.

31. Wyman J B, Dent J , and Holloway RH. Changes in oesophageal $\mathrm{pH}$ associated with gastro-oesophageal reflux. Are traditional criteria sensitivefor detection of reflux? Scand J Gastroenterol 28: 827-832, 1993.

32. Zerbib F, Bruley des Varannes S, R ozé C, and GalmicheJ P. Etudesimultanée des tonus du sphincter inférieur del'oesophage et de l'estomac proximal chez I'homme sain. Gastroenterol Clin Biol 20: 1078-1083, 1996.

33. Zerbib F, Bruley des Varannes S, Scarpignato C, Leray V, D'Amato M, Rozé C, and Galmiche J P. E ndogenous cholecystokinin in postprandial lower esophageal sphincter function and fundic tone in humans. Am J Physiol Gastrointest Liver Physiol 275: G1266-G1273, 1998.

34. Zerbib F, Bruley des Varannes S, Ropert A, Lamouliatte $H$, Quinton A, and Galmiche J P. Proximal gastric tone in gastroæesophageal reflux disease. Eur J Gastroenterol Hepatol 11: 511-515, 1999. 